памятника археологии, поискать в данной местности ранние названия и по возможности подкрепить этимологию неочевидных названий указанием на обнаруженные здесь археологические древности. Например, название деревни Кострони в Новгородской области получило приемлемое объяснение от др.-рус. костьрь 'укрепление, башня' ввиду того, что вблизи деревни было открыто средневековое укрепленное городище.

Агеева Р. А. Гидронимия Русского Северо-Запада как источник культурноисторической информации. М., 1989.

Крысько В. Б. Древний новгородско-псковский диалект на общеславянском фоне // Вопр. языкознания. 1998. № 3. С. 74-93.

Седов $B$. B. Некоторые ареалы архаических славянских гидронимов и археология // Перспективы развития славянской ономастики : сб. ст. / отв. ред. А. В. Суперанская, Н. В. Подольская. М., 1980.

Trubetzkoy $N$. Die altkirchenslavische Vertretung der urslav. * $t j,{ }^{*} d j / /$ Zeitschrift für slavische Philologie. 1927. Bd. 13. S. 88-97.

DOI 10.31168/7996-2700-3.23

\author{
Н. В. Васильева \\ Институт языкознания РАН \\ Москва, Россия \\ vasileva-natalia@yandex.ru
}

\title{
Безымянность как категория ономастики: металингвистические заметки
}

Относится ли безымянность к концептуальному и терминологическому полю ономастики? С одной стороны, А. К. Матвеев, обсуждая термин аноним, писал, что «он обозначает не группу собственных имен, а отсутствие имени, его неизвестность, безымянность и находится вне ономастической рубрикации. Поэтому бессмысленны термины *анони́мика, *анони́мия. Нельзя изучать то, чего нет» [Матвеев, 2005, 8]. С другой стороны, литературоведами все же предлагается обобщающий термин для интерпретации фикциональных текстов, построенных на безымянности как поэтической доминанте, а именно:

(C) Васильева Н. В., 2019 
Anonymastik - «нулевой» коррелят литературной ономастики [Stiegler, 1994, 279]. Таким образом, безымянность сродни морфологическому нулю, и есть основание для того, чтобы описать категорию безымянности как особое терминологическое поле в рамках кластерного (собранного по различным полям) словаря терминов литературной ономастики.

Как нам уже доводилось писать [Васильева, 2009], у лингвистов, которые так или иначе обращались к проблеме безымянности, возникало желание видоизменить это русское слово, освободить его от груза общеупотребительности и тем самым терминологизировать, приблизить к термину имя. То есть сделать так, чтобы имя четче зазвучало внутри термина, имя отрицающего. Поэтому предлагались формы безыменность [Фужерон, 2001] и безымение (устное сообщение С. Е. Никитиной).

Для структурирования концептуального и терминологического поля безымянности представляется целесообразным сначала объединить безымянность / анонимность в единый семантический комплекс, а затем выделить различные виды безымянности в текстах. Таких видов получается три, и образно их можно назвать ликами безымянности: безымянность как неимение имени (безымянность ${ }_{1}$, р. безымянная речка), безымянность как незнание имени (безымянность ${ }_{2}$ ср. безымянные герои) и безымянность = анонимность, т. е. сокрытие имени (безымянность ${ }_{3}$ ср. анонимный звонок). Достаточно очевидно, что безымянность становится категорией только в связке «имя $\leftrightarrow$ безымянность». Если исходить из того, что у безымянности три лика, а переходы в тексте возможны как от имени к безымянности, так и от безымянности к имени, то мы получим шесть вариантов переходов, т. е. «безымянность ${ }_{1,2,3} \rightarrow$ имя» и «имя $\rightarrow$ безымянность ${ }_{1,2,3}$ ». С этих позиций наречение именем, например, является переходом «безымянность $\rightarrow$ имя», а текстовая интродукция персонажа с называнием его имени адресату - переходом «безымянность ${ }_{2} \rightarrow$ имя». Такое структурирование концептуального пространства безымянности в фикциональных текстах позволяет не только точнее охарактеризовать безымянность как текстовую стратегию, но и привести в некоторую систему термины и различные выражения, которые используются в филологических трудах при рассуждениях о безымянности, ср. умолчание имени, отказ от имени, неназывание по имени (nomina sunt odiosa [ср.: Безродный, 1994]), криптоним, псевдоним, аллюзия и др. 
Безродный М. В. Об одном приеме художественного имяупотребления: nomina sunt odiosa // Литературный текст: Проблемы и методы исследования. Тверь, 1994. C. $157-164$.

Васильева Н. В. Собственное имя в мире текста. М., 2009.

Матвеев А. К. Ономастика и ономатология: терминологический этюд// Вопр. ономастики. 2005. № 2. С. 5-10.

Фужерон И. Имя и «безыменность» как прием расстановки сил и выражения авторского отношения к персонажам (на примере рассказов В. Гроссмана) // Имя: внутренняя структура, семантическая аура, контекст : тез. докл. междунар. науч. конф : в 2 ч. / отв. ред. Т. М. Николаева. М., 2001. Ч. 2. С. 153-157.

Stiegler B. Die Aufgabe des Namens. Untersuchungen zur Funktion der Eigennamen in der Literatur des zwanzigsten Jahrhunderts. München, 1994.

DOI 10.31168/7996-2700-3.24

\section{И. Т. Вепрева}

Уральский федеральный университет

Екатеринбург, Россия

irina_vepreva@mail.ru

\section{Эргонимы Екатеринбурга \\ в коммуникативно-прагматическом аспекте}

Урбанонимы в ономастическом пространстве современного мегаполиса являются динамично развивающейся группой, обладающей, помимо номинативной функции, функцией речевого воздействия на горожанина, выступающего в роли адресата в диалоге с номинатором, автором эргонима. В номинациях городских коммерческих объектов находят отражение активные языковые процессы, отмечаемые на современном этапе развития русского языка. При функциональном многообразии эргонимов (легко запоминаться, вызывать положительные ассоциации, быть понятными благодаря своей внутренней форме) на первое место выходит прагматическая нагрузка эргонима — эпатировать городского жителя своей экспрессивностью.

Прагматические намерения номинатора, создателя коммерческого имени, - создать новые номинативные модели, которые бы обладали особым видом стилистической окраски - экспрессией новизны 